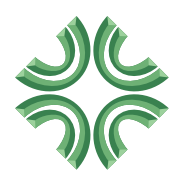

CLIINICAS

PORTO ALEGRE RS
Revista

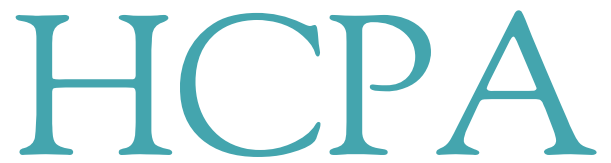

REVISTA DO HOSPITAL DE C LÍNICAS DE PORTO A L E RE E FACULDADE DE MEDICINA DA UNIVERSIDADE DO RIO GRANDE DO SUL

REVISTA HCPA 2005; 25 (Supl 1) :1-251
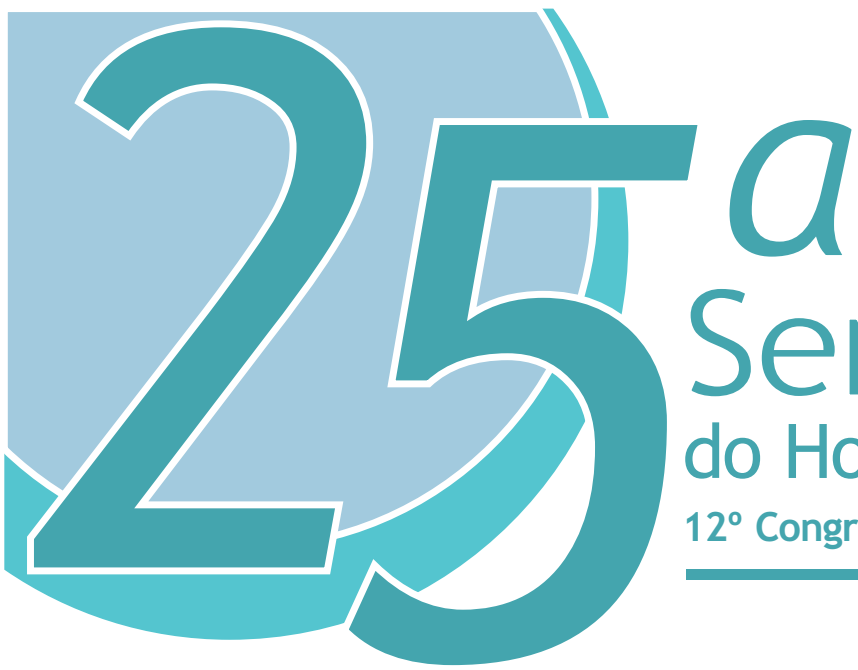

Semana Científica do Hospital de Clínicas de Porto Alegre

$12^{\circ}$ Congresso de Pesquisa e Desenvolvimento em Saúde do Mercosul

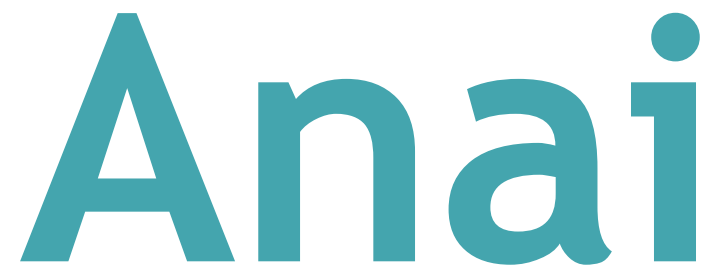




\section{INTERLEUKIN-6 SERUM LEVELS IN PATIENTS WITH PARKINSON'S DISEASE}

KERLY WOLLMEISTER HOFMANN;DANIELE FRICKE; RENATA LEKE; ARTHUR FRANCISCO SCHUMACHER SCHUH; LUIS VALMOR CRUZ PORTELA; MáRCIA LORENA FAGUNDES CHAVES; CARLOS ROBERTO DE MELLO RIEDER

Interleukin-6 (IL-6) concentrations have been reported to be elevated in post mortem brain and cerebrospinal fluid (CSF) of levodpa (L-DOPA) treated Parkinsonl's disease (PD) patients. Aim of this study is to evaluate the levels of IL-6 in the serum of PD patients and the effects of drugs and disease severity on it. IL- 6 was measured in the serum of 23 control subjects, 17 PD patients without antiparkinsonian drug therapy and 23 PD patients with LDOPA therapy using high sensitivity enzyme-linked immunosorbent assays (ELISA). The levels of IL-6 ( $p>0,05)$ between the two groups of PD patients and controls were similar. However, IL-6 levels correlated negatively with the Activities of Daily Living (ADL) scale $(r=-0,457 ; p<0,05)$, indicating that the severity of disease was associated with the levels of IL-6. No influence of age and medication appeared. Disturbance of IL-6 levels may lead to neurons dopaminergic degeneration in the substantia nigra, and to apoptosis neuronal and/or glial. Because the IL- 6 is known to play a key role in the interaction between the nervous and immune system, our results suggest that only marginal effects occurs on the peripheral immune system, and that neuroimmune dysfunctions found for other studies in post mortem brain and CSF in the PD patients seem to be limited to the central nervous system (CNS). 